\title{
PENERAPAN MODEL PEMBELAJARAN MAKE A MATCH UNTUK MENINGKATKAN PRESTASI BELAJAR BAHASA INGGRIS
}

\author{
Miyarti \\ SMP Negeri 1 Bulu, Kabupaten Sukoharjo \\ dramiyarti@yahoo.co.id
}

\begin{abstract}
Abstrak
Penelitian ini bertujuan untuk meningkatkan prestasi belajar IPA melalui model pembelajaran kooperatif tipe jigsaw pada siswa kelas IX A SMP Negeri 1 Tawangsari tahun pelajaran 20192020. Subjek penelitian tindakan kelas ini adalah siswa kelas IX A SMP Negeri 1 Tawangsari tahun pelajaran 2019-2020 sebanyak 32 siswa sebagai subjek penerima tindakan, sedangkan untuk subjek pelaku tindakan adalah guru IPA kelas IX A selaku guru, teman sejawat selaku subjek yang melakukan observasi proses pembelajaran, Kepala Sekolah selaku subjek sumber data. Metode pengumpulan data dilakukan melalui teknik tes, observasi dan dokumentasi. Penelitian Tindakan ini dilakukan dalam dua siklus, tiap-tiap siklus terdiri dari: perencanaan, tindakan, pengamatan dan refleksi. Hasil penelitian ini menunjukkan bahwa penggunaan model pembelajaran kooperatif tipe jigsaw dapat meningkatkan prestasi belajar IPA siswa kelas IX A SMP Negeri 1Tawangsari tahun pelajaran 2019-2020. Hal ini dapat dilihat dari nilai rata-rata prestasi belajar IPA siswa juga mengalami peningkatan yaitu sebelum tindakan sebesar 71, pada siklus I sebesar 77 dan pada siklus II sebesar 85 . Selain itu, presentase ketuntasan belajar siswa, yaitu sebelum tindakan sebesar $47 \%$, pada siklus I sebesar $66 \%$ dan pada siklus II sebesar $97 \%$.
\end{abstract}

Kata kunci : pembelajaran kooperatif, jigsaw, prestasi belajar IPA

\begin{abstract}
The aim of this research is to improve achievement of studying science of IX A students of SMP Negeri 1 Tawangsari at academic year 2019-2020 by means of applying cooperative learning model type jigsaw. This research is a classroom action research which was conducted in two cycles. The subject of this research is the IX A students with total number of 32 students. This research is conducted by the science teacher of IX A, other science teacher as colleague who observes the learning process, and the Headmaster as subject to source of the data. The method of collecting data is conducted by test technique, observation and documentation. This classroom action research is conducted in two cycles, each of which consisting of four stages namely, planning, implementation, observation and reflection. The result of data analysis shows that by means of applying cooperative learning model type jigsaw there is an improvement of achievement of studying science of IX A students of SMP Negeri 1 Tawangsari Sukoharjo at academic year 2019-2020. There is an improvement of achievement of studying science average: 71 before the reserach, 77 after first cycle and 85 after the second cycle. Besides, the classical completeness average is also improved: $47 \%$ before the reserach, $66 \%$ after first cycle, and $97 \%$ after the second cycle.
\end{abstract}


Keywords : cooperative learning, jigsaw type, achievement of studying science

\section{PENDAHULUAN}

Proses pembelajaran IPA tidak selamanya berjalan efektif karena masih ada beberapa siswa yang mengalami kesulitan dalam belajar IPA. Banyak siswa memandang pelajaran IPA sangat membosankan dan kurang penting, karena belajar IPA harus banyak membaca dan menghafal materi pelajaran yang saling berkaitan. Pelajaran IPA dianggap tidak menarik sehingga kurang diminati dan bahkan dihindari oleh sebagian besar siswa. Siswa seharusnya sadar bahwa di masa datang para siswa akan menghadapi tantangan berat karena kehidupan masyarakat global selalu mengalami perubahan setiap saat. Dan oleh karena itu mata pelajaran IPA dirancang untuk mengembangkan pengetahuan, pemahaman dan kemampuan analisis terhadap kondisi sosial masyarakat dalam memasuki kehidupan bermasyarakat yang dinamis.

Rendahnya prestasi belajar IPA siswa disebabkan karena aktivitas dalam pembelajaran IPA masih sangat rendah. Siswa jarang sekali mengajukan pertanyaan walaupun guru telah memancing dengan pertanyaan-pertanyaan yang sekirannya siswa belum jelas. Selain itu, aktivitas siswa dalam membaca, memahami materi, mengemukakan pendapat dan bekerja kelompok masih rendah.

Kendala lain dalam proses pembelajaran IPA adalah model pembelajaran yang dipakai guru dalam menyampaikan pelajaran. Namun dalam pembelajaran di sekolah, umumnya guru menggunakan model pembelajaran kelompok biasa. Model pembelajaran kelompok biasa untuk mata pelajaran IPA tentu kurang relevan dan akan menimbulkan kesenjangan bagi pemahaman siswa. Dalam pembelajaran menggunakan model kelompok biasa sebenarnya bukan sejauh mana siswa paham dengan materi yang diajarkan tetapi sejauh mana guru bisa menyampaikan materi itu. Sehingga siswa hanya mendengar apa yang diterangkan oleh guru yang akhirnya siswa tidak terbiasa mengemukakan ide-ide atau gagasan yang ada dalam pikirannya. Inilah yang membuat siswa menjadi pasif dan akhirnya malas untuk mengembangkan kemampuan berfikirnya. Rendahnya 
aktivitas siswa tersebut dapat mengakibatkan proses belajar yang telah disajikan oleh guru menjadi tidak tuntas dan tidak paham dengan materi tersebut.

Berkaitan dengan hal tersebut, permasalahan yang sama terjadi di SMP Negeri 1 Tawangsari dimana kegiatan pembelajaran hanya berpusat pada guru sehingga sebagian besar siswanya menjadi pasif dan tidak terlibat aktif. Berdasarkan hasil ulangan IPA materi Sistem Reproduksi Manusia pada siswa kelas IX A SMP Negeri 1 Tawangsari, didapatkan 66\% siswa yang tuntas melebihi KKM dari siswa kelas IX A sebanyak 32 siswa. KKM IPA di SMP Negeri 1 Tawangsari adalah 72.

Prestasi belajar merupakan salah satu indikator mutu pendidikan ditinjau dari segi hasil. Prestasi diterjemahkan sebagai hasil usaha atau hasil yang telah dicapai, dilakukan atau dikerjakan (Poerwodarminto, 1976). Prestasi dalam kaitanya dengan belajar berarti suatu hasil usaha setelah seseorang melakukan usaha belajar. Menurut Arifin (1990) "prestasi merupakan kemampuan ketrampilan dan sikap seseorang dalam menyelesaikan suatu hal". Kemampuan seseorang dalam menyelesaikan suatu permasalahan baik dari segi kualitas maupun kuantitas merupakan suatu bentuk prestasi.

IPA merupakan gabungan dari unsur-unsur Geografi, Sejarah, Hukum dan Politik, Kewarganegaraan, Sosiologi, bahkan juga bidang humaniora, pendidikandan agama (Numan Soemantri, 2001). Dapat diambil kesimpulan bahwa prestasi belajar adalah prestasi belajar yang dicapai siswa dalam proses belajar mengajar yang ditunjukkan dengan nilai tes yang diberikan oleh guru, sehingga terdapat proses perubahan dalam pemikiran serta tingkah laku. Sedangkan prestasi belajar IPA adalah hasil dari aktivitas siswa dalam belajar masalah IPA, mengorganisir tugas belajar yang berhubungan dengan masalah sosial tersebut. Mengumpulkan informasi yang sesuai dengan melaksanakan eksperimen untuk mendapatkan penjelalasan dari pemecahan masalah tersebut.

Setiap guru tentunya menginginkan pada saat proses belajar mengajar terjadi suatu interaksi antara guru dan siswa maupun antar sesama siswa. Hal ini menunjukkan bahwa dalam proses belajar mengajar dikelas siswa lebih aktif dan lebih bersemangat. Dengan kondisi tersebut guru akan lebih mudah dalam 
menyampaikan materi pelajaran karena pada siswa akan merespon dan memahami dengan baik. Prestasi belajar IPA pun dapat mengalami peningkatan.

Untuk meningkatkan kemampuan berpikir dan aktivitas siswa sehingga prestasi belajar IPA dapat meningkat yakni perlu adanya variasi dalam proses belajarnya. Adanya variasi pembelajaran agar siswa bisa lebih aktif dalam proses kegiatan belajar mengajar didalam kelas. Model pembelajaran yang bervariasi tersebut artinya dalam penggunaan model mengajar tidak harus selalu sama untuk setiap pokok bahasan karena bisa saja terjadi bahwa suatu modeltertentu cocok untuk satu pokok bahasan namun tidak cocok untuk pokok bahasan yang lain.

Salah satu variasi dalam pembelajaran yakni dengan menerapkan model pembelajaran kooperatif. Metode pembelajaran sangat banyak macamnya, tetapi dalam hal ini digunakan metode Jigsaw dalam pembelajaran IPA. Metode Jigsaw dikembangkan oleh Welliot Aronson dan diadopsi oleh Slavin dan disarikan oleh TIM (2004) Penerapan metode Jigsaw dalam pembelajaran diawali dengan pembagian siswa dalam kelompok kecil dengan 5-6 anggota secara heterogen. Materi pembelajaran diberikan pada siswa dalam bentuk teks yang telah dibagi dalam beberapa sub bab. Setiap anggota diberi tugas untuk membaca sub bab dan bertanggungjawab untuk mempelajari bagian yang diberikan. Anggota dari kelompok lain melakukan kegiatan yang sama. Selanjutnya masing -masing anggota kelompok yang bertanggung jawab pada sub bab yang sama bertemu dalam kelompok ahli. Mereka mendiskusikan materi yang telah dibaca dan menjadi tanggungjawabnya. Setelah selesai mendiskusikan materi dalam kelompok ahli, anggota kelompok kembali pada kelompok asal. Selanjutnya masing - masing anggota kelompok menyampaikan hasil diskusi dari tiap kelompok ahli.

Langkah-langkah model pembelajaran metode Jigsaw: (1) Pilihlah materi pelajaran yang dapat dibagi menjadi beberapa segmen (bagian), (2) Bagi peserta didik menjadi beberapa kelompok sesuai dengan jumlah segmen yang ada. Jika jumlah peserta didik adalah 32 siswa, sementara jumlah segmen yang ada adalah 4, maka masing-masing kelompok terdiri dari 8 siswa. Jika jumlah ini dianggap terlalu besar, bagi lagi menjadi dua, sehingga setiap kelompok terdiri dari 4 orang, 
kemudian setelah proses selesai gabungkan kedua kelompok pecahan tersebut, (3) Setiap kelompok mendapat tugas membaca dan memahami materi pelajaran yang berbeda, (4) Setiap kelompok mengirimkan anggotanya ke kelompok lain untuk menyampaikan apa yang telah mereka pelajari di kelompok, (5) Kembalikan suasana kelas seperti semula kemudian tanyakan sekiranya ada persoalanpersoalan yang tidak terpecahkan dalam kelompok, (6) Beri peserta didik beberapa pertanyaan untuk mengecek pemahaman mereka terhadap materi.

Berdasarkan uraian di atas, dapat dirumuskan tujuan penelitian ini adalah untuk: Meningkatkan prestasi belajar IPA menggunakan metode Jigsaw pada siswa kelas IX A semester I SMP Negeri 1 Tawangsari tahun pelajaran 20192020 .

\section{METODE PENELITIAN}

Penelitian ini adalah Penelitian Tindakan Kelas (PTK), merupakan suatu pencermatan terhadap kegiatan yang sengaja dimunculkan, dan terjadi dalam sebuah kelas (Arikunto, 2010: 130). Penelitian ini dilaksanakan di SMP Negeri 1 Tawangsari. Tahap-tahap pelaksanaan kegiatan dilak ukan selama kurang lebih lima bulan yaitu sejak bulan Juli sampai dengan bulan November 2019. Subjek penelitian tindakan kelas ini adalah siswa kelas IX A SMP Negeri 1 Tawangsari semester 2 tahun pelajaran 2019-2020 sebanyak 32 siswa yang terdiri dari 14 siswa laki-laki dan 18 siswa perempuan, sebagai subjek penerima tindakan, sedangkan untuk subjek pelaku tindakan adalah guru IPA kelas IX A selaku guru, teman sejawat selaku subjek yang melakukan observasi proses pembelajaran, Kepala Sekolah selaku subjek sumber data. Metode pengumpulan data dilakukan melalui teknik tes, observasi dan dokumentasi.

Teknik pengumpulan data yang digunakan adalah: (a) Tes, observasi, dan dokumentasi. Metode tes digunakan untuk memperoleh data tentang prestasi belajar IPA siswa sebelum penelitian, selama penelitian dan setelah penelitian dilaksanakan.Observasi yang digunakan adalah observasi sistematis, yaitu observasi yang dilakukan oleh pengamat dengan menggunakan pedoman sebagai instrumen pengamatan. 
Instrumen yang digunakan dalam penelitian ini adalah: lembar observasi, tes, dan dokumentasi. Lembar observasi dugunakan peneliti sebagai pedoman melakukan observasi atau pengamatan guna memperoleh data yang akurat dalam pengamatan. Lembar observasi juga digunakan untuk memonitor dan mengevaluasi setiap tindakan agar kegiatan observasi tidak terlepas dari konteks permasalahan dan tujuan penelitian. Tes digunakan untuk melihat seberapa besar penguasaan konsep IPA siswa terhadap materi yang diajarkan. Hasil tes dianalisis guna mengetahui penguasaan materi IPA setelah dilakukan model pembelajaran jigsaw. Indikator keberhasilan dalam penelitian ini adalah apabila nilai rata-rata tes siswa sekurang-kurangnya 80,0 dan banyak siswa dengan nilai di atas batas ketuntasan minimal (KKM) yaitu $\geq 72,0$ mencapai $\geq 90 \%$.

\section{HASIL PENELITIAN DAN PEMBAHASAN}

Berdasarkan hasil pretest, dari 32 siswa yang mencapai nilai kriteria ketuntasan minimal (KKM) yaitu 72 sebanyak 15 siswa (47\%) dan siswa yang tidak mencapai nilai kriteria ketuntasan minimal (KKM) sebanyak 17 siswa (53\%) dengan nilai rata-rata kelas sebesar 66. Guru hanya menerapkan model ceramah dan siswa hanya disuruh mendengarkan dan mencatat apa yang diperlukan. Hasil ini dapat ditampilkan pada grafik berikut.

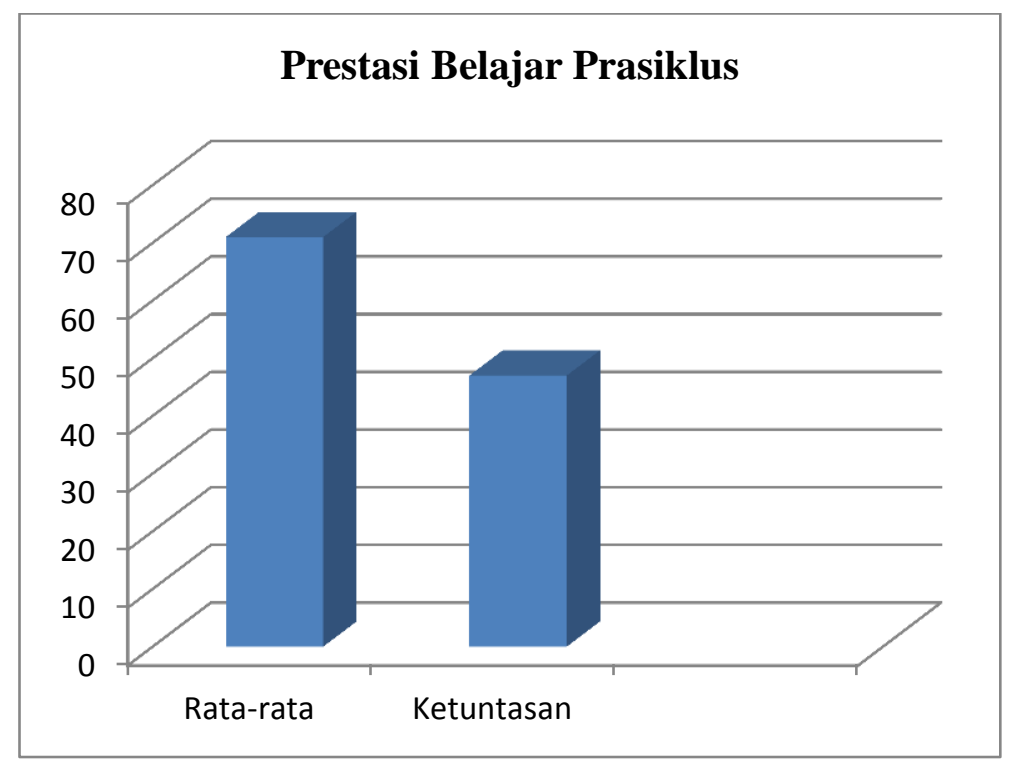

Gambar 1. Grafik Prestasi belajar IPA Siswa pada Prasiklus 
Salah satu solusi yang dikembangkan adalah penggunaan model pembelajaran kooperatif tipe jigsaw. Dengan penggunaan model pembelajaran tersebut diharapkan akan menciptakan suasana belajar yang berbeda, bervariasi dan menyenangkan sehingga dapat menarik perhatian siswa dan meningkatkan prestasi belajar siswa.

\section{Tindakan Siklus I}

Pembelajaran dilaksanakan dengan pedoman Rencana Pelaksanaan Pembelajaran (RPP) selama 2 kali pertemuan ( 2 x 80 menit). Kompetensi Dasar yang disampaikan pada siklus I adalah Peta tentang pola dan bentuk-bentuk muka bumi. Setelah langkah apersepsi dilanjutkan dengan penyampaian materi dengan model pembelajaran tipe jigsaw.

Model pembelajaran tipe jigsaw dilaksanakan dengan menggunakan langkah-langkah sebagai berikut: (1) Pendahuluan berisi kegiatan guru memberi salam, mengkondisikan kelas, mengecek presensi siswa dan melakikan appersepsi. Guru menyampaikan tujuan pembelajaran yang ingin dicapai dan memberi motivasi belajar; (2) Kegiatan inti tentang pelaksanaan kegiatan model pembelajaran kooperatif tipe JIigsaw sebagai berikut: Guru membagi siswa menjadi 8 kelompok secara heterogen, selanjutnya kedelapan kelompok ini disebut kelompok asal. Guru menyampaikan pembagian materi/soal pada setiap anggota kelompok.

Siswa dengan materi/soal yang sama bergabung dalam kelompok ahli dan berusaha menguasai materi sesuai dengan bagiannya. Guru memberikan bantuan seperlunya. Setelah selesai mendiskusikan materi dalam kelompok ahli, anggota kelompok kembali pada kelompok asal. Selanjutnya masing-masing anggota kelompok menyampaikan hasil diskusinya di kelompok ahli. Tiap siswa dalam kelompok asal saling menularkan dan menerima materi dari siswa lain. Setelah siswa berdiskusi dalam kelompok ahli maupun kelompok asal, selanjutnya dilakukan presentasi masing-masing kelompok atau dilakukan pengundian salah satu kelompok untuk menyajikan hasil diskusi. Agar guru dapat menyamakan persepsi pada materi pembelajaran yang telah didiskusikan. (3) Kegiatan penutup 
yaitu guru bersama-sama siswa menyimpulkan materi yang telah dipelajari. Guru memberikan kuis secara individual. Guru memberikan penghargaan kepada kelompok asal yang yang nilai rata-ratanya tinggi. Guru memberitahukan materi pertemuan selanjutnya kepada siswa dan menutup pelajaran dengan berdoa dan salam.

Hasil observasi menunjukkan bahwa guru telah melaksanakan kegiatan pembelajaran dengan cukup baik, yaitu guru mengajar dengan arah dan tujuan yang jelas. Namun ketika guru menyampaikan materi dengan model pembelajaran kooperatif tipe jigsaw, beberapa siswa tampak masih kurang memperhatikan, dan beraktivitas sendiri. Selain itu tidak semua kelompok dapat berdiskusi dengan baik.

Berdasarkan hasil evaluasi pada siklus I menunjukkan adanya peningkatan prestasi belajar siswa. Rata-rata prestasi belajar siswa pada siklus I adalah 77, sebanyak 21 siswa (66\%) mencapai nilai kriteria ketuntasan minimal (KKM), dan sebanyak 11 siswa (34\%) tidak mencapai nilai kriteria ketuntasan minimal (KKM). Berdasarkan hasil tersebut dapat diketahui bahwa proses pembelajaran pada siklus pertama sudah meningkatkan prestasi belajar tetapi belum berjalan dengan cukup baik serta belum mencapai indikator kinerja yang diharapkan. Hasil ini dapat ditampilkan pada grafik berikut.

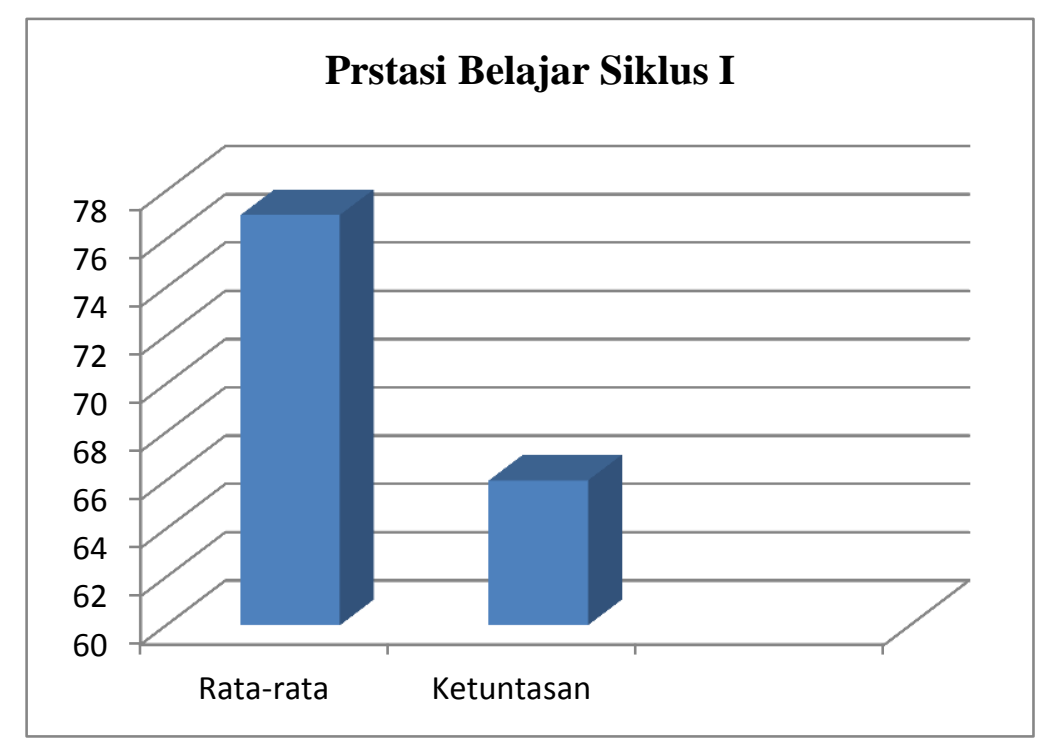

Gambar 2. Grafik Prestasi belajar IPA Siswa pada Siklus I 
Keberhasilan yang dicapai setelah siklus I hanya sebagian siswa yang menunjukkan partisipasi yang meningkat sementara siswa lainnya masih pasif. Refleksi terhadap faktor-faktor yang menjadi penyebab kurangnya partisipasi siswa adalah: (1) Sebagian siswa belum bisa mengikuti langkah-langkah pembelajaran model pembelajaran kooperatif tipe jigsaw; (2) Kerjasama dalam kelompok berdiskusi belum maksimal; (3) Hanya siswa tertentu saja yang dapat memahami materi dan soal yang diberikan kepada setiap kelompok.

\section{Tindakan Siklus II}

Pembelajaran dilaksanakan dengan pedoman Rencana Pelaksanaan Pembelajaran (RPP) selama 2 x pertemuan (2 x 80 menit). Setelah langkah apersepsi dilanjutkan dengan penyampaian materi dengan model pembelajaran tipe Jigsaw.Pada pelaksanaan siklus II ini, kegiatan pembelajaran dilaksanakan dengan proses sebagai berikut. (1) Guru mengulang sekilas materi yang telah disampaikan kemudian melanjutkan materi yang baru dengan model pembelajaran kooperatif tipe Jigsaw seperti pada siklus I, tetapi jumlah anggota kelompok 4 siswa, dan guru melakukan tanya jawab dengan siswa; (2) Guru memberikan latihan soal-soal dengan model pembelajaran kooperatif tipe Jigsaw; langkah selanjutnya seperti pada siklus I; (6) Guru memberikan postest dan tugas rumah.

Berdasarkan kegiatan observasi, secara garis besar diperoleh gambaran pelaksanaan tindakan siklus II ada peningkatan prestasi belajar siswa. Dalam pertemuan ini banyak siswa mampu menjawab soal-soal yang diberikan dengan benar dan baik. Sebagian siswa aktif dalam bertanya dan mengemukakan ide mereka. Siswa juga dapat memahami materi yang telah diajarkan hal ini terlihat dari cara siswa menyelesaikan soal-soal.

Berdasarkan hasil evaluasi pada siklus II menunjukkan adanya peningkatan prestasi belajar siswa. Rata-rata prestasi belajar siswa pada siklus II adalah 85 sebanyak 31 siswa (97\%) mencapai nilai kriteria ketuntasan minimal (KKM), dan sebanyak 1 siswa (3\%) tidak mencapai nilai kriteria ketuntasan minimal (KKM). Hasil ini dapat ditampilkan pada grafik berikut. 


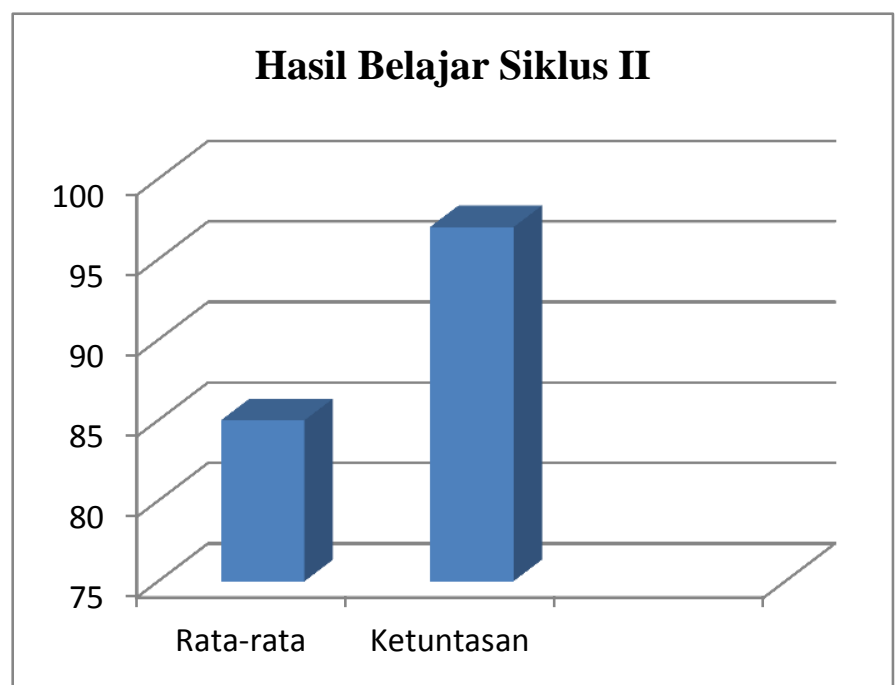

\section{Gambar 3. Grafik Prestasi belajar IPA Siswa pada Siklus II}

Sebagian siswa menunjukkan partisipasinya meningkat dari siklus II. Keberhasilan yang dicapai setelah siklus II telah memenuhi indikator keberhasilan penelitian ini, sehingga tindakan ini tidak diteruskan atau dihentikan pada siklus II.

Berdasarkan pengolahan dan analisis data di atas, maka diperoleh interpretasi bahwa penerapan model pembelajaran kooperatif tipe jigsaw terhadap peningkatan prestasi belajar siswa menunjukkan bahwa terjadi peningkatan prestasi belajar siswa pada sebelum tindakan siklus I, dan pada siklus I ke siklus II. Terjadi peningkatan prestasi belajar siswa ini sebagai efek dari meningkatkan keterampilan sosial dan kemandirian siswa yaitu adanya perhatiaan siswa dalam proses belajar, kerjasama dalam tiap pasangan kelompok dan kemandirian dalam mengerjakan soal.

Hal ini dapat dilihat dari hasil penelitian dari siklus pertama sampai dengan siklus ketiga dapat diringkaskan seperti terlihat pada tabel sebagai berikut: Hasil analisis evaluasi yang dilaksanakan pada setiap siklus diperoleh peningkatan prestasi belajar siswa.Hal ini dapat dilihat pada nilai rata-rata siswa dan persentase ketuntasan hasil belajar siswa pada setiap siklus yang mengalami peningkatan. 
Tabel 1. Peningkatan Hasil Belajar Pra Siklus, Siklus I, dan Siklus II

\begin{tabular}{ccccccc}
\hline No & Faktor & $\begin{array}{c}\text { Pra } \\
\text { Siklus }\end{array}$ & Siklus I & Siklus II & Indikator & Ket \\
\hline 1 & $\begin{array}{c}\text { Rata-rata } \\
\text { kelas }\end{array}$ & 71 & 77 & 85 & $\geq 80,00$ & Tercapai \\
\hline 2 & $\begin{array}{c}\text { Ketuntasan } \\
\text { belajar }\end{array}$ & $47 \%$ & $66 \%$ & $97 \%$ & $90 \%$ & Tercapai \\
\hline
\end{tabular}

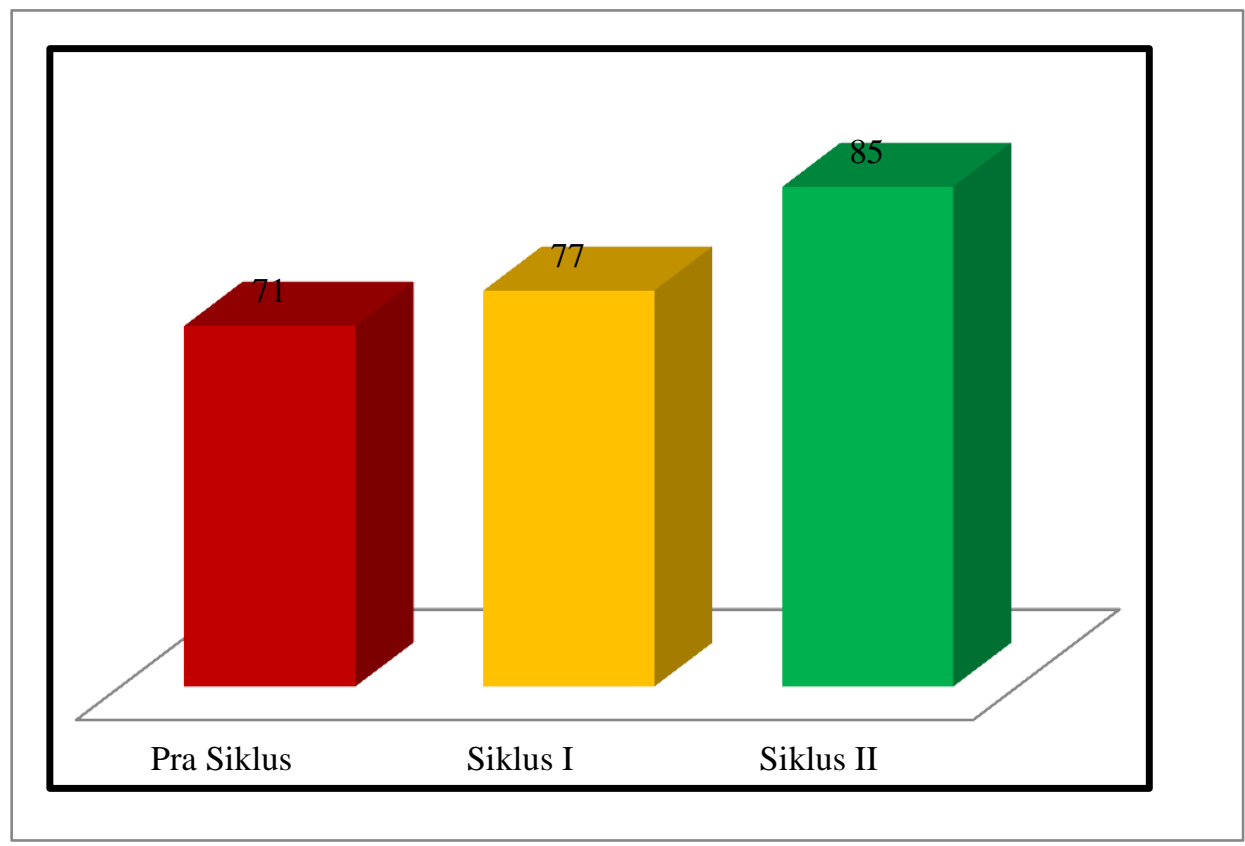

Gambar 4. Grafik Perbandingan Prestasi belajar IPA Siswa pada Prasiklus, Siklus I, dan Siklus II

Dari tabel dan grafik di atas dapat disimpulkan bahwa prestasi belajar IPA siswa dengan menerapkan model pembelajaran kooperatif tipe jigsaw di setiap putaran mengalami peningkatan, yaitu: (1) Sebelum dilakukan tindakan, nilai ratarata prestasi belajar siswa adalah 71 sedangkan persentase ketuntasan 47\%; (2) Setelah dilakukan tindakan pada siklus I, nilai rata-rata prestasi belajar IPA siswa mengalami peningkatan yaitu 77 dengan persentase ketuntasan $66 \%$, tetapi belum mencapai indikator yang diharapkan; (3) Pada siklus II, nilai prestasi belajar siswa meningkat yaitu menjadi 85 dengan persentase ketuntasan sebesar 97\% dan sudah mencapai indikator yang diharapkan maka penelitian tindakan kelas ini sudah berhasil. 
Rata-rata prestasi belajar IPA siswa pada siklus II sebesar $85 \geq 80,0$ (indikator kinerja) dan persentase ketuntasan siklus II sebesar 97\% $\geq 90 \%$ (indikator kinerja). Jadi, indikator kinerja sudah tercapai sehingga tidak dilanjutkan ke siklus berikutnya.

\section{SIMPULAN DAN SARAN}

Penggunaan model pembelajaran kooperatif tipe Jigsaw dapat meningkatkan prestasi belajar IPA siswa kelas IX A SMP Negeri 1 Tawangsari tahun pelajaran 2019-2020. Hal ini dapat dilihat dari nilai rata-rata prestasi belajar IPA siswa juga mengalami peningkatan yaitu sebelum tindakan sebesar 71, pada siklus I sebesar 77 dan pada siklus II sebesar 85. Selain itu, presentase ketuntasan belajar siswa, yaitu sebelum tindakan sebesar $47 \% \%$, pada siklus I sebesar $66 \%$ dan pada siklus II sebesar $97 \%$.

Berdasarkan hasil dari simpulan di atas maka peneliti memberikan saransaran sebagai berikut: (1) Agar para guru di SMP Negeri 1 Tawangsari dalam pelaksanaan pembelajaran IPA menerapkan metode Jigsaw untuk meningkatkan prestasi belajar IPA siswa kelas IX, (2) Siswa disarankan agar lebih aktif dalam pembelajaran baik secara individu maupun kelompok dalam pelaksanaan pembelajaran IPA menggunakan metode Jigsaw, dan (3) Sekolah dapat mengambil kebijakan agar para guru di SMP Negeri 1 Tawangsari selalu menggunakan model pembelajaran yang inovatif dan menyenangkan dalam proses belajar mengajar untuk meningkatkan prestasi siswa.

\section{DAFTAR PUSTAKA}

Arifin Zaenal. 1990. Evaluasi Instruksional Prinsip-Teknik prosedur. Bandung: Remadja Rosdakarya.

Astuti, Siti Irene. 2007. Desentralilsasi Pendidikan dan Ketimpangan Mutu pada tingkat Satuan Pendidikan. Makalah Simposium Nasional 2007, Jakarta 26-27 Juli 2007. Pusat Penelitian Kebijakan dan Inovasi Pendidikan, Balitbang, Depdiknas RI. 
Den Brok, P.et. al. 2002. Diagnosin and Improving The Quality of Techers Inter Persolen Behaviar. The Internasional Journal of Educational Management. Vol. 16, No. 4176 - 184, MBC Up Limited.

Depdiknas. 2003. Indikator Pendidikan di Indonesia. Jakarta: LitBang Depdiknas.

Iskandar, Srini M. 2006. Peningkatan Kualitas Pembelajaran Dasar-dasar Sains dengan Menggunakan Pembelajaran Berkelompok (Learning Together) dan Pembelajaran Timbal Balik (Reciprocal Teaching). Jurnal Penelitian Kependidikan.

Joyce, B. dan Marsha Weil. 1996. Models of Teaching. Needham Heights: Allyn \& Bacon.

Poerwadarminta. 1976. Kamus Besar Bahasa Indonesia. Jakarta: Balai Pustaka.

Slavin, Robert, E. 1995. Cooperatif Learning Research and Practise. Boston: Allyn \& Bacon.

Sukmadinata, N.S., dkk. 2002. Pengendalian mutu pendidikan sekolah menegah. Bandung: Kesuma Karya.

Tim PTBK. 2004. Buku Panduan Materi Pelatihan Terintegrasi Berbasis Kompetensi. Jakarta: Depdiknas. 